\title{
Predictors of Behavioural Intentions of Teachers to Adopt and Use Information and Communication Technologies in Secondary Schools in Zimbabwe
}

\author{
Norman Rudhumbu* \\ College of Education, University of South Africa, Pretoria Campus, South Africa \\ https://orcid.org/0000-0002-2536-5511 \\ Elizabeth Du Plessis \\ College of Education, University of South Africa, Pretoria Campus, South Africa \\ https:// orcid.org/0000-0003-4299-4632 \\ Patience Kelebogile Mudau \\ College of Education, University of South Africa, Pretoria Campus, South Africa \\ https://orcid.org/0000-0002-5389-6942
}

\begin{abstract}
The use of information and communication technologies (ICTs) also known as educational technology in the teaching and learning context, has become a new normal in all sectors of education world-wide. The most important driver of the use of ICT in education has been the rapid advances in technology and to some extent, natural disasters such as COVID-19 that has affected access to education across all sectors of the education system. As a result, it has become very important that teachers in secondary schools adopt ICT for their teaching. This study therefore seeks to establish factors influencing the behavioural intentions of secondary school teachers to adopt ICT in Zimbabwe. A sample of 251 teachers were selected using stratified random sampling strategy from 10 secondary schools to participate in the study. A structured questionnaire adapted from the Oscarson Scale for Measuring Adoption-proneness (OSMA) was used for data collection. Results of the study showed that the use of technology in teaching, professional development, attitudes toward ICT, gender and ICT support services have a significant influence on the behavioural intentions of secondary school teachers to adopt ICT. A number of challenges that affected the adoption of ICT in secondary schools were also identified. The study has implications
\end{abstract}

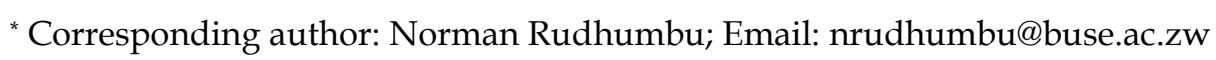

(C)Authors

This work is licensed under a Creative Commons Attribution-NonCommercial-NoDerivatives 4.0

International License (CC BY-NC-ND 4.0). 
on both policy and practice with regard to the adoption of ICT in secondary schools.

Keywords: attitudes towards ICT; behavioural intention; ICT adoption; information communication technology; Technology Adoption Model

\section{Introduction}

The introduction of ICT in schools has become critical in facilitating e-learning and enhancing access to education. Critically, the use of ICT in schools has been found to promote the use of innovative teaching approaches, ensure collaboration among students and develop technological skills of both teachers and students (Christopoulos \& Sprangers, 2021). Also, the advent of pandemics such as COVD19 has made it even more imperative that teachers adopt ICT in schools (UNESCO, 2020). De-Graft (2018) also argues that technology-mediated teaching is now a universally accepted mode of teaching in today's classrooms, hence it is critical that teachers adopt ICT and also demonstrate technology self-efficacy to be able to effectively integrate technology in teaching. Studies by Christopoulos et al. (2018), Mayer (2019) and Zhu and Urhahne (2018) found that while advances in ICT have forced schools to integrate technology in teaching and learning, a great deal still needs to be done to establish while the integration of ICT in secondary schools is still not effective. This is also supported by Reich (2020) who in his study argued that while technology use in schools has become ubiquitous, the use of technology in the teaching and learning processes has failed to disrupt how teachers teach and students learn as teachers continue to use traditional methods of teaching. While some studies show that limited staff and student motivation to use ICT in the teaching and learning process (Christopoulos et al., 2018; Scherer et al., 2019; Tondeur et al., 2017), the absence of a structured way of integrating technology in the teaching and learning process (Vongkulluksn et al., 2018 ), and a lack of funding and resources in schools (Francom, 2020; Nikolopoulou \& Gialamas, 2015) are some of the factors affecting the integration of ICT in schools, more research is still needed for a wholesome identification of more factors. The need for more research on factors influencing the integration of ICT in secondary is also confirmed in the results of a study by OECD (2019), which found that slightly above half $(57 \%)$ of secondary school teachers feel prepared to use ICT for teaching, around 59\% of secondary school teachers let their students use ICT for learning, and also that about half (50\%) need professional development and of these, $18 \%$ need urgent professional development in ICT.

The adoption of technology in Zimbabwe has become a common phenomenon especially due to both advances in ICT and the advent of COVID-19 (UNESCO, 2020). A number of studies (OECD, 2019; Reich, 2020; UNESCO, 2020) have alluded to its wide adoption and also pointed to the fact that the adoption process has not been smooth due to a number of challenges. In the context of Zimbabwe, despite the wide adoption of ICT in schools, there is no study that has been conducted to establish factors that influence behavioural intentions of secondary school teachers to adopt ICT in secondary school. This study therefore is an 
attempt to bridge this research gap. The research objectives guiding the study are to:

1. Establish factors that influence the behavioural intentions of secondary school teachers to adopt ICT,

2. Identify barriers to ICT adoption by male and female teachers in secondary schools in Zimbabwe

3. Determine whether gender has a significant influence on the behavioural intentions of secondary school teachers to adopt ICT.

\section{Literature review}

\subsection{The concept of Information and communication technology}

Modern societies that include educational systems are increasingly relying on ICTs as the main drivers of knowledge generation (UNESCO, 2017). In the context of education systems, the rapid advances in ICTs the world over has enhanced the teaching/learning process by improving the quality of learning, transforming conventional delivery systems, and sustaining lifelong learning for all (UNESCO, 2017; Musarurwa, 2018; Dzinotyiweyi \& Taddese, 2020). These rapid advances in ICTs have challenged teachers to be more creative and innovative in the way they deliver instruction to today's technology-savvy learners in schools (Odhiambo, 2013). This is also confirmed by Baishakhi and Kamal (2016) who argued that the digital age has enabled huge flows of information for both teachers and learners, hence the need for teachers to have both the knowledge and skills to apply the new digital tools has become more persuasive than ever before. ICTs have been understood and defined variously.

One of the widely used definitions is that ICTs relate to a wide range of technological tools and resources that are used to communicate, create, disseminate, store and manage information (Mishra, Sharma \& Tripathi, 2008). ICT is also defined as a set of digital tools that are used for facilitating the processing, transmission and display of information (Hamadin, 2017). When used in the context of teaching and learning, ICT is referred to as educational technology, which specifically relates to a combination of telephones, computers, software, modems, internet, e-mails, CD-ROMs, televisions and radios that facilitate teaching and learning (Gebre et al., 2014; Hamadin, 2017; Kong, 2019; Reyna, 2016). Among some of the benefits of ICTs in education include the expanding of access to learning as learners can now access information from anywhere and at any time, improvement of the quality of learning, and improvement in learners' performance (Ghavifekr \& Rosdy, 2015; Machivenyika, 2018; Odhiambo, 2013).

\subsection{Contextual framework: Information and communication technology use in Zimbabwe schools}

In the context of Zimbabwe, the history of the integration of ICT in the education system in general and in secondary schools in particular dates back to 2005 when the Zimbabwean government introduced the National ICT policy, which was later reviewed in 2016 and re-launched in 2018 (Manhibi, 2019; Musarurwa, 2018; Zimbabwe Ministry of Primary and Secondary Education, 2019; Zimbabwe National Statistics Agency, 2017). The main gist of this policy with regard to the 
education system was to capacitate schools and teachers with technological gadgets, knowledge and skills to be able to successfully integrate ICTs in their teaching. To this extent, the government of Zimbabwe donated computers to many of the urban and rural schools and also mandated colleges and universities to provide computer training to teachers (Musarurwa, 2018; Manhibi, 2019; Konyana \& Konyana, 2013).

Furthermore, in Zimbabwe, like in many of the African countries, a number of challenges continue to affect the adoption of ICTs by teachers. The reviewed 2005 National ICT policy in Zimbabwe alluded to the following challenges as affecting the adoption of ICT in the education system: (i) inadequate ICT infrastructure, (ii) inadequate or unreliable electricity supplies, and (iii) the low digital literacy levels of teachers (Manhibi, 2019; Musarurwa, 2018). A number of studies also alluded to these challenges. Machivenyika (2018), Mandina (2015) and UNESCO (2017) argue that the main challenges affecting ICT adoption in schools in Zimbabwe include (i) capacity-related challenges where teachers lacked the necessary skills and knowledge to confidently integrate ICTs in their teaching, (ii) policy/planning-related challenges where inadequate mapping of ICT initiatives, a lack of coordination among key ICT stakeholders, and a lack of resources were critical challenges, and (iii) inadequate ICT infrastructure and prohibitive costs of internet connectivity, maintenance equipment, power, and assistive technologies.

\section{Theoretical and conceptual frameworks informing hypotheses formulation}

This study is informed by the Technology Adoption Model (TAM) developed by Davis (1989). The model is premised on the belief that four factors namely attitudes towards ICT, perceived usefulness, perceived ease of use and behavioural intention to use ICT help us understand why people adopt or fail to adopt and use ICT (Teo et al., 2015; Hamadin, 2017; Orser et al., 2019). Separate studies by Broos (2005), Teo et al. (2015), Kong (2019) and Gebre et al. (2014) found that attitudes towards ICT significantly influenced behavioural intentions to adopt and use ICT. Behavioural intention (BI) is defined as an expression or measure of a person's intention to act in a particular way or to perform a specific task (Rudhumbu, 2020). Perceived ease of use is defined as the degree to which users feel that using an ICT tool is going to be effortless (Kong, 2019; Teo et al., 2015). With regard to perceived ease of use, studies by Mutisya and Makokha (2016), Teo (2019) and Wong, Teo and Russo (2012) found that behavioural intention to adopt and use ICT develops in people who feel that it is going to be ease for them to use an ICT gadget to perform their tasks. Perceived usefulness is also defined as the degree to which users feel that by using a particular ICT gadget, the performance of their tasks is going to be more productive than without the gadget (Wong et al., 2012; Attis, 2014). In the context of the current study, a research model (Figure 1), adapted from the TAM model, was developed.

\subsection{Use of ICT in teaching}

Anecdotal evidence with regard to the benefits of using ICT for teaching abound (Tondeur et al., 2017). Use of ICT in teaching refers to the use of digital resources, digital communication tools and the collection of data to effectively support 
teaching and learning, promote interaction and facilitate pedagogical decision making in classrooms (Kong, 2019; Gebre et al., 2014; Orser et al., 2019). A study by Perrotta (2013) found that ICT use in education assists teachers in carrying out various tasks, namely searching for information and preparing learning materials; presenting information (e.g. using Power Point presentations, interactive whiteboards and data projectors); collecting and managing data about learners' activities; collaborating with colleagues; communicating with learners and parents; and sharing resources to the wider education community (Kong, 2019). Studies by Teo et al. (2015), Kong (2019), Orser et al. (2019) and Wong et al (2012) found that teachers who believe that the use of ICT for teaching will make the performance of their tasks easier and more productive, develop behavioural intentions to adopt ICT. This is also confirmed in a study by Tri Anni et al. (2018) which established that teachers who perceived ICT as being useful to the performance of their tasks tended to develop behavioural intentions to adopt the ICT.

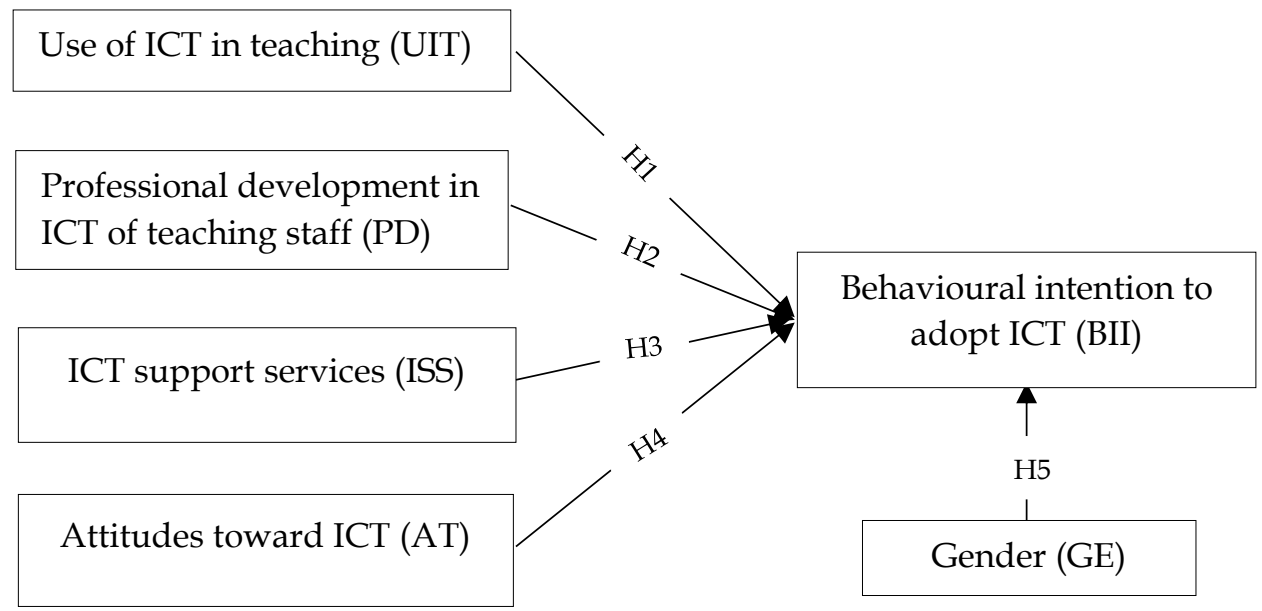

Figure 1: Research model

\subsection{Professional development in ICT of teaching staff}

The role of professional development of teaching staff in ICT is to enable them to effectively use ICT in the performance of their duties. Professional development in ICT is key to enabling and supporting teachers to use ICT in classrooms (Williams et al., 2000). This is also confirmed by Dlamini and Mbata (2018) who argued that the implementation of effective and meaningful teacher professional development is critical for the development of digital fluency and innovative pedagogies by teachers. Studies by Abuhmaid (2011), Binglimas (2009), Buckenmeyer (2010) and Welch (2012) found that by allowing teachers to deepen their ICT knowledge and skills through professional development, schools help change teachers' beliefs towards ICT thereby promoting their behavioural intentions to adopt ICT in classrooms. Separate studies by Marios (2020) and De Clercq and Shalem (2014) also found that teacher professional development in ICT helps teachers acquire particular ICT knowledge and skills sets that help in the development of confidence and behavioural intentions by the teachers to adopt ICT for teaching. In their study Mansour et al. (2011) also found that empowering teachers through professional development in ICT improves their behavioural 
intentions to use technology for teaching. Another study by Thatcher and Perrewé (2012) found that professional development reduces ICT anxiety and boosts confidence in teachers thus improving behavioural intentions to adopt ICT. Schoonenboom (2014) in his study also found that abilities, skills and competences developed in teachers as a result of training significantly contribute to their behavioural intentions to adopt ICT.

\subsection{ICT support services}

Having adequate ICT support infrastructure through a well-trained team of ICT support team as well as a supportive institutional leadership motivates teachers to adopt technology. According to Rudhumbu (2020), the successful adoption and use of ICT requires a supportive environment as demonstrated through the availability of ICT tools, systems and support teams capable of promoting and sustaining the behavioural intentions of teachers to adopt and use ICT. Studies by Baturay et al. (2017) and Teeroovengadum et al. (2017) also found that a supportive institutional environment that has adequate ICT systems maintenance and update tools, adequately trained support personnel, and a supportive leadership, is a vehicle for promoting behavioural intentions of teachers to adopt ICT in schools.

\subsection{Attitude towards ICT and adoption of ICT}

Attitudes represent a person's disposition to something. Various studies that include studies by Venkatesh and Bala (2008) and Teo et al. (2008) found that the success of technology adoption and actual use by teachers in schools depends to a large extent on their attitudes towards ICT, since attitudes, whether negative or positive, define how a person responds to ICT. Confirming the importance of attitudes on the behavioural intentions of teachers to adopt and actually use ICT, a study by De-Graft (2018) found that positive attitudes towards ICT are critical to the successful adoption and use of ICT by teachers in their teaching.

\subsection{Gender and ICT adoption}

The issue of the influence of gender on ICT adoption in educational institutions has been widely discussed and researched. Studies on gender differences on ICT adoption and use in educational settings have shown mixed results (Orser et al., 2019; Dosaya et al., 2020). This is confirmed by Teo et al. (2015, p.236) who argued that, "the issue of gender differences in the use of technology in the classroom has emerged with mixed findings in a number of research investigations". Studies by Aung and Khaing (2016), Kay (2006), Mutuku (2018), Dosaya, et al. (2020) and Teo et al. (2015) found that the gender of a teacher was a critical factor in technology adoption in schools as female teachers tended to use ICT less when teaching due to their limited access to ICT tools as well as their limited ICT skills levels.

A number of studies have shown that male teachers adopt and use technology more than female teachers when teaching (Ardies et al., 2015) because they are more confident and technologically active than female teachers. Studies by Hayes (2007), Rudhumbu (2020) and Wang (2010) found that male teachers use technology more in their teaching because they are overall more confident and task-oriented than female teachers. As Dosaya, et al. (2020) found in their study, 
female teachers are more likely to use technology for teaching only when they perceive the technology to be easy to use. Orji (2010) argues that differences between men and women with regards to behavioural intentions to use ICT have been widely studied and results tended to be more favourable to men. A study by Pham et al. (2020) also found that there are significant differences between male and female teachers with regard to behavioural intentions to adopt and use technology due to the fact that male teachers hold the belief that using technology helps them perform their tasks better and also that female teachers mostly use technology when they believe the effort required to use technology is minimum. These results were also confirmed in studies by Attis (2014) and Pham et al. (2020) whose results showed that male teachers are more likely to integrate technology in their teaching than female teachers because of their positive attitudes.

\section{Hypotheses}

$\mathrm{H}_{1}$ : Use of ICT in teaching has a significant and positive influence on the attitudes of secondary school teachers towards ICT.

$\mathrm{H}_{2}$ : Professional development of teaching staff in ICT has a significant and positive influence on the attitudes of secondary school towards ICT.

$\mathrm{H}_{3}$ : ICT support services have a significant and positive influence on the attitudes of secondary school teachers towards ICT.

$\mathrm{H}_{4}$ : Attitudes towards ICT have a significant and positive influence on the behavioural intentions of secondary school teachers to adopt ICT.

$\mathrm{H}_{5}$ : Gender has a significant and positive influence on the attitudes of secondary school teachers towards ICT.

\section{Methods and materials}

\subsection{Research design and instrument development}

The study employed a descriptive research design. A descriptive research design is a design in which researchers aim to establish characteristics, frequencies, trends, and categories of a phenomenon by answering the questions: what, how, where and when (Creswell \& Plano Clark, 2017; McCombes, 2020). A 47-item structured questionnaire (shown in Appendix) adapted from the Oscarson Scale for Measuring Adoption-proneness (OSMA) was used for data collection. The OSMA was developed by Oscarson (1976) and comprises of 81 items spread across 5 different factors as follows: attitudes towards ICT - 19 items; use of ICT in teaching - 21 items; professional development of teaching staff - 6 items; ICT support services - 6 items; and barriers to adoption and use of ICT - 29 items. The OSMA used a 6 - point Likert scale from No, never (1) to Yes, always (6). The structured questionnaire for the current study has 47 items as follows: attitudes towards ICT - 8 items; use of ICT in teaching - 10 items; professional development of teaching staff-6 items; ICT support services - 5 items; gender - 4 items; behavioural intentions to adopt ICT - 4 items, and barriers to adoption and use of ICT - 10 items. In the current study, the questionnaire used a 5-point Likert scale from Strongly disagree (SDA - 1), Disagree (A - 2), Neutral (N - 3), Agree (A - 4) to Strongly agree (SA - 5). The new instrument was different from the OSMA in that it also assessed the moderating influence of gender in the adoption of ICT by secondary school teachers. Confirmatory factor Analysis (CFA) was used for assessing the data structure, that is, to measure the validity and reliability of the 
data collected using the self-developed structured questionnaire. For ease of analysis, a criterion mean $(\mathrm{CM})$ calculated as the mean of the scale items was calculated as follows: $\mathrm{CM}=(5+4+3+2+1) / 5=3.0$. Based on the $\mathrm{CM}$, a response with a mean score of less than 3.0 shows disagreement with a given assertion, while a response with a mean score of above 3.0 shows agreement with a given assertion.

\subsection{Population and sampling strategies}

The population for the study comprised of secondary school teachers in the Mashonaland Central urban region of Zimbabwe. Ten secondary schools were purposively selected based on the fact that they have computer laboratories and their curricula include courses in computer studies hence such schools were considered rich sources of data for the study on ICT adoption. Purposive sampling strategy is defined as a sampling strategy in which individuals or units that are considered information rich are targeted and selected for a study (Creswell \& Plano Clark, 2017). With regard to the respondents to the study, stratified random sampling strategy was used for selecting 251 teachers from a population of 320 teachers from the 10 schools. The sample size was determined using the Research Advisors' (2006) online sample size table at 95\% degree of confidence and $2.5 \%$ margin of error. Stratified random sampling strategy is defined as a probability sampling procedure that is used primarily on quantitative-oriented studies in which various subgroups (strata) in a population of interest are proportionately represented in the study sample (Creswell \& Plano Clark, 2017). The selected teachers teach from Form one to four in the following areas of specialization: Sciences, Commerce, Creative Arts, as well as Arts and Social Sciences. Based on stratified random sampling, each of the 10 participating institutions were represented in the study sample as follows: $X 1=24 ; X 2=26$; $X 3=44 ; X 4=31 ; X 5=27 ; X 6=27 ; X 8=18 ; X 9=20 ; X 10=32$. A total of 251 questionnaires were delivered to the teachers through the offices of Headmasters and 166 were returned giving a return rate of $66.3 \%$.

\subsection{Data analysis}

The Software Package for Social Sciences (SPSS) version 24 was used for data analysis. Measurement model analysis was done using the Kaiser-Meyer-Olkin (KMO) measure of sampling adequacy and the Bartlett Bartlett's test of Sphericity to demonstrate the suitability of the data structure for Confirmatory Factor Analysis (CFA). Regression analysis was used to test hypothesized relationships.

\section{Results}

5.1. Analysis of demographic data

Table 1: Demographic factors of teachers

\begin{tabular}{ccc}
\hline Demographic factor & Factor items & Frequency $\%$ \\
\hline Age & $20-30$ years & 28 \\
& $31-40$ years & 35 \\
$41-50$ years & 26 \\
& $>50$ years & 11
\end{tabular}




\begin{tabular}{ccc} 
Gender & Male & 59 \\
Educational level & Female & 41 \\
& Certificate in Education & 5 \\
& Diploma in Education & 39 \\
& Bachelor's degree & 52 \\
Teaching experience & Master's degree & 4 \\
& $<5$ years & 25 \\
& $5-10$ years & 37 \\
Level taught & $11-20$ years & 25 \\
& $>$ 20 years & 13 \\
& Form 1 & 35 \\
Area of specialization & Form 2 & 29 \\
& Form 3 & 19 \\
& Form 4 & 31 \\
& Sciences & 45 \\
& Arts and Social Sciences & 14 \\
& Commerce & 4 \\
& Creative Arts & 6 \\
\hline
\end{tabular}

Results in Table 1 represent the analysis of demographic data of secondary school teachers who participated in the study. It is shown from the results that most of the teachers $(63 \%)$ are aged 40 years and younger and the rest $(37 \%)$ were older than 40 . This shows that secondary schools are populated by relatively young teachers. With regard to gender, most of secondary school teachers (59\%) are male while $41 \%$ are female teachers. Gender balance is still an issue in secondary schools in Zimbabwe. 56\% of secondary school teachers have either a bachelor's or a master's degree qualification while $44 \%$ have either a certificate or diploma qualification. This shows that most of the secondary school teachers in Zimbabwe have a degree qualification. With regard to years of teaching experience, $62 \%$ of teachers have 10 years and less of teaching experience which resonates with the fact that most of the teachers are 40 years and younger. With regard to levels taught, most of the teachers $(64 \%)$ teach either Form one or Form two levels and this resonates with the fact that Form one and two classes are always the largest in secondary schools hence most of the teachers are found in these lower levels. With regard to areas of specialization of teachers, results show that the majority of the teachers $(45 \%)$ are found in the Arts and Social Sciences areas while the lowest number $(4 \%)$ is found in Creative Arts.

\subsection{Measurement model analysis}

Table 2: KMO and Bartlett test on independent variables

\begin{tabular}{lrr}
\hline \multicolumn{3}{c}{ KMO and Bartlett test } \\
\hline Kaiser-Meyer-Olkin Measure of Sampling Adequacy & .859 \\
Bartlett's test of Sphericity & Approx. Chi-Square & 305.209 \\
& Df. & 158 \\
& Sig. & .000 \\
\hline
\end{tabular}

Results in Table 2 demonstrate the suitability of the data structure for factor analysis to be conducted. Two tests, namely the KMO and Bartlett's tests were 
conducted to confirm the above. The Kaiser-Meyer-Olkin Measure of sampling adequacy was .859 , demonstrating that the data satisfied the benchmark of KMO $\geq .05$ (Hair et al., 2017), hence showing that a factor analysis could be conducted. Results of the Bartlett's test of Sphericity (BS) of 305.209, which were significant $(p=.000)$ also satisfied the benchmark of $p<.05$ (Hair et al., 2017) further confirming that factor analysis could be performed to validate the data.

Table 3: Convergent validity and reliability measurement of the model

\begin{tabular}{|c|c|c|c|c|c|c|}
\hline $\begin{array}{l}\text { Model } \\
\text { Constructs }\end{array}$ & $\begin{array}{l}\text { Measurement } \\
\text { Items }\end{array}$ & $\begin{array}{c}\lambda \\
(\lambda>.6)\end{array}$ & $\begin{array}{c}\text { IIR } \\
\text { (IRR } \\
>.6 \text { ) }\end{array}$ & $\begin{array}{c}\mathrm{CA} \\
(\mathrm{CA}>.7)\end{array}$ & $\begin{array}{c}\mathrm{CR} \\
(\mathrm{CR}>.7)\end{array}$ & $\begin{array}{c}\text { AVE } \\
(\mathrm{AVE}>.5)\end{array}$ \\
\hline \multirow[t]{5}{*}{ UIT } & UIT2 & .720 & $\begin{array}{l}.681 \\
\end{array}$ & .843 & .910 & 739 \\
\hline & UIT3 & .805 & .847 & & & \\
\hline & UIT4 & .715 & .702 & & & \\
\hline & UIT6 & .724 & .713 & & & \\
\hline & UIT9 & .801 & .749 & & & \\
\hline \multirow[t]{4}{*}{ PD } & PD1 & .727 & .910 & .901 & .949 & .613 \\
\hline & PD2 & 811 & .739 & & & \\
\hline & PD3 & .745 & .646 & & & \\
\hline & PD5 & .826 & .829 & & & \\
\hline \multirow[t]{5}{*}{ ISS } & ISS1 & .817 & .751 & .783 & .804 & 619 \\
\hline & ISS2 & .804 & .855 & & & \\
\hline & ISS3 & .742 & .631 & & & \\
\hline & ISS4 & .902 & .772 & & & \\
\hline & ISS5 & .751 & .810 & & & \\
\hline \multirow[t]{5}{*}{ AT } & AT1 & .715 & .801 & .814 & .827 & 651 \\
\hline & AT2 & 839 & .772 & & & \\
\hline & AT3 & .651 & .749 & & & \\
\hline & AT4 & .826 & .813 & & & \\
\hline & AT5 & .805 & .829 & & & \\
\hline \multirow[t]{3}{*}{ GE } & GE1 & .749 & .805 & .827 & .914 & .742 \\
\hline & GE3 & .815 & .933 & & & \\
\hline & GE4 & .741 & .748 & & & \\
\hline \multirow[t]{4}{*}{ BII } & BII1 & .833 & .683 & .735 & .761 & .603 \\
\hline & BII2 & 749 & .759 & & & \\
\hline & BII3 & .910 & .843 & & & \\
\hline & BII4 & .701 & .810 & & & \\
\hline \multirow[t]{10}{*}{ BA } & BA1 & .812 & .761 & .801 & .841 & .644 \\
\hline & BA2 & .759 & .812 & & & \\
\hline & BA3 & .815 & .741 & & & \\
\hline & BA4 & .704 & .673 & & & \\
\hline & BA5 & .837 & .775 & & & \\
\hline & BA6 & .746 & .826 & & & \\
\hline & BA7 & 810 & .819 & & & \\
\hline & BA8 & .761 & .783 & & & \\
\hline & BA9 & .744 & .803 & & & \\
\hline & BA10 & .769 & .661 & & & \\
\hline
\end{tabular}

Notes: $\lambda$ - Standardised factor loadings; IIR - Individual item reliability; CA - Cronbach's alpha; $C R$ - Composite reliability, AVE - Average variance extracted.

Table 3 shows a test of reliability and convergent validity of data items. Internal consistency reliability was tested through Cronbach's alpha (a) of each of the constructs. The results in Table 3 show that a values ranged between .735 and 
.901 , which satisfied the minimum requirement of $a \geq .7$ for adequate internal consistence reliability of scale items (Hair et al., 2017). Results in Table 3 also confirmed convergent validity through standardized factor loadings, Cronbach's alpha, composite reliability and average variance extracted (Hair et al., 2014). Standardized factor loadings ranged between .651 and .910, individual item reliability values ranged between .631 and .933 , Cronbach's alpha values ranged from .735 and .901 , composite reliability values ranged between .761 and .949 , and average variance extracted (AVE) values ranged from .603 and .742, confirming the presence of convergent validity in the scale items (Hair et al., 2017).

Table 4: Discriminant validity measurement

\begin{tabular}{lccccccc}
\hline Constructs & BII & UIT & PD & ISS & AT & GE & BA \\
\hline BII & .777 & & & & & & \\
UIT & $.419^{* * *}$ & .860 & & & & & \\
PD & $.631^{* * *}$ & $.319^{* * *}$ & .783 & & & & \\
ISS & $.547^{* * *}$ & $.261^{*}$ & $.539^{*}$ & .787 & & & \\
AT & $.601^{* * *}$ & $.227^{*}$ & $.317^{* *}$ & $.355^{* * *}$ & .807 & & \\
GE & $.133^{* * *}$ & $.436^{* * *}$ & $.421^{* *}$ & $.641^{* *}$ & $.301^{*}$ & .861 & \\
BA & $-.408^{* * *}$ & $-.517^{* *}$ & $-.298^{* *}$ & $-.447^{* *}$ & $.268^{* *}$ & $-.305^{*}$ & .802 \\
\hline
\end{tabular}

Notes: Bold values represent the square roots of AVE; Significant: ${ }^{*} p<.05 ;{ }^{* *} p<.01$; $* * * p<.001$

Table 4 shows a test of discriminant validity of scale items. A comparison of the values of the square roots of AVE (bold diagonal values) and the vertical interconstruct correlations for each of the constructs show that all the diagonal values were greater than the corresponding vertical values for each construct thus satisfying requirements of discriminant validity (Hair et al., 2017). Except for BA, all independent factors have a significant and positive association with BII with PD having the strongest association with BII $(r=.631 ; \mathrm{p}<.001)$ and GE having the weakest association with BII $(r=.133 ; p<.001)$. Except for BA, all factors have positive associations with each other with GE and ISS having the strongest association $(\mathrm{r}=.641 ; \mathrm{p}<.01)$, showing that more ICT support is required according to the gender of teachers. AT and UIT have the weakest positive association among the factors $(\mathrm{r}=.227 ; \mathrm{p}<05)$, demonstrating that attitudes of teachers does not affect the use of ICT for teaching by teachers much.

\subsection{Barriers to ICT adoption and use in secondary schools}

This section analyses barriers to ICT adoption in secondary schools in Zimbabwe as a means of demonstrating why the adoption of ICT assumes a very slow pace in these schools.

Table 5: Barriers to ICT adoption by male and female teachers

\begin{tabular}{ccccc}
\hline & Nature of challenge & Gender & Mean & SD \\
\hline 1 & Lack of ICT training & Male & 3.19 & .615 \\
& & Female & 4.26 & .672 \\
2 & Inadequate ICT resources & Male & 3.71 & .803 \\
& & Female & 3.74 & .636 \\
3 & Inadequate ICT support & Male & 3.41 & .715 \\
& & Female & 4.06 & .609
\end{tabular}




\begin{tabular}{|c|c|c|c|c|}
\hline \multirow[t]{2}{*}{4} & High internet costs & Male & 4.07 & .613 \\
\hline & & Female & 4.10 & .723 \\
\hline \multirow[t]{2}{*}{5} & Slow internet connectivity & Male & 4.33 & .819 \\
\hline & & Female & 4.29 & .741 \\
\hline \multirow[t]{2}{*}{6} & High costs of ICT gadgets & Male & 2.62 & 682 \\
\hline & & Female & 2.65 & .705 \\
\hline \multirow[t]{2}{*}{7} & Techno-phobia & Male & 1.92 & .622 \\
\hline & & Female & 4.15 & .718 \\
\hline \multirow[t]{2}{*}{8} & High workloads & Male & 3.98 & .657 \\
\hline & & Female & 3.85 & .711 \\
\hline 9 & $\begin{array}{l}\text { Negative perceptions } \\
\text { towards ICT }\end{array}$ & Male & 2.19 & .827 \\
\hline \multirow{3}{*}{10} & & Female & 3.84 & .801 \\
\hline & Lack of confidence & Male & 1.08 & 652 \\
\hline & & Female & 3.91 & .618 \\
\hline
\end{tabular}

Results in Table 5 show that secondary school teachers face a number of challenges that affect their adoption and use of ICT in classrooms. While in many cases both male and female teachers agree on the nature and type of challenges they face, results show gendered differences on the extent to which each of the two groups feel that each of the given challenges affects them. Results show that a lack of ICT training, which contributes to limited competences affects female teachers $(\mathrm{M}=4.26 ; \mathrm{SD}=.672)$ more that male teachers $(\mathrm{M}=3.19 ; \mathrm{SD}=.615)$. Both male and female teachers believe that inadequate ICT resources are a challenge in their adoption and use of ICT in classrooms and this slightly affects female teachers $(\mathrm{M}=3.74 ; \mathrm{SD}=.636)$ more than male teachers $(\mathrm{M}=3.71 ; \mathrm{SD}=.803)$. High internet costs have also been identified as a challenge in ICT adoption and affects female teachers $(M=4.10 ; S D=.723)$ more than male teachers $(M=4.07 ; S D=.613)$. Slow internet connectivity is viewed as the single biggest challenge affecting the adoption and use of ICT by both male teachers $(\mathrm{M}=4.33$; $\mathrm{SD}=.819)$ and female teachers $(\mathrm{M}=4.29 ; \mathrm{SD}=.741)$, with male teachers being affected more than female teachers.

The cost of ICT gadgets is not a challenge to both male $(\mathrm{M}=2.62 ; \mathrm{SD}=.682)$ and female $(M=2.65 ; \mathrm{SD}=.705)$ teachers and hence does not affect their adoption and use of ICT in classrooms. Techno-phobia is not viewed as a challenge by male teachers $(\mathrm{M}=1.92 ; \mathrm{SD}=.622)$ but is viewed as a serious challenge by female teachers $(\mathrm{M}=4.15 ; \mathrm{SD}=.718)$. This shows that the fear of technology is seriously affecting female teachers' behavioural intention to adopt and use technology in classrooms. High workloads are challenges affecting both female teachers $(\mathrm{M}=3.85 ; \mathrm{SD}=.711)$ and male teachers $(M=3.98 ; S D=.657)$, with male teachers being affected more than female teachers. A negative perception towards ICT is a challenge affecting the adoption and use of ICT by female teachers $(\mathrm{M}=3.84 ; \mathrm{SD}=.801)$ and not a challenge for male teachers $(M=2.19 ; \mathrm{SD}=.857)$. Female teachers also face the challenge of lack of a confidence $(\mathrm{M}=3.91 ; \mathrm{SD}=.618)$ to use ICT and this affects their behavioural intentions to adopt and use ICT while male teachers do not have the challenge of a lack of confidence $(\mathrm{M}=1.08 ; \mathrm{SD}=.652)$ when using ICT in classrooms. 


\subsection{Test of multicollinearity}

This section tests assumptions of multicollinearity using tolerance levels (TL) and Variance inflation factor (VIF) to determine whether or not assumptions of multicollinearity were violated.

Table 6: Tolerance Test and Variance Inflation Factor

\begin{tabular}{lcc}
\hline Variance & \multicolumn{2}{c}{ Collinearity statistics } \\
& Tolerance Level (TL) & $\begin{array}{c}\text { Variance Inflation Factor } \\
\text { (VIF) }\end{array}$ \\
\hline UIT & .725 & 2.033 \\
PD & .803 & 1.917 \\
ISS & .668 & 1.958 \\
AT & .551 & 2.447 \\
GE & .715 & 3.725 \\
BII & .649 & 2.692 \\
BA & .739 & 4.019 \\
\hline
\end{tabular}

The results in Table 6 show that TL $<1.0$ and VIF $<10$ demonstrating that the assumptions of multicollinearity were satisfied in the study hence to show inference in the study would not be affected (Hair et al., 2017).

\subsection{Hypotheses testing}

This section tested hypothesized relationship between independent variables (use of ICT in teaching, professional development in ICT of teaching staff, ICT support services, attitude toward ICT and gender) and the dependent variable (behavioural intention to adopt ICT).

Table 7: Model summary and regression coefficients of independent variables

\begin{tabular}{|c|c|c|c|c|c|c|c|c|}
\hline \multirow[t]{2}{*}{ Model } & \multirow{2}{*}{$\begin{array}{c}\text { Unstandardized } \\
\text { coefficients } \\
\text { B }\end{array}$} & \multirow{2}{*}{$\begin{array}{c}\text { Standard } \\
\text { Error } \\
\text { SE }\end{array}$} & \multirow{2}{*}{$\begin{array}{c}\text { Standardized } \\
\text { coefficients } \\
\beta\end{array}$} & \multirow[b]{2}{*}{$\mathrm{t}$} & \multicolumn{4}{|c|}{$\begin{array}{c}95 \% \\
\text { confidence } \\
\text { interval for B }\end{array}$} \\
\hline & & & & & Sig. & $\begin{array}{l}\text { Lower } \\
\text { bound }\end{array}$ & $\begin{array}{l}\text { Upper } \\
\text { bound }\end{array}$ & $\mathrm{R}^{2}$ \\
\hline 1 & & & & & & & & \\
\hline (Constant) & .300 & .475 & & .092 & .817 & .295 & .320 & \\
\hline UIT & .213 & .022 & .483 & 5.701 & .003 & .205 & .230 & .47 \\
\hline PD & .127 & .037 & .365 & 3.664 & .007 & .105 & .131 & .58 \\
\hline ISS & .091 & .014 & .329 & 7.382 & .000 & .075 & .105 & .51 \\
\hline AT & .341 & .045 & .301 & 13.266 & .000 & .326 & .350 & .49 \\
\hline GE & .118 & .033 & .103 & 4.825 & .010 & .115 & .130 & .62 \\
\hline
\end{tabular}

Notes: Significant: $p<.05$; Dependent variable: Behavioural intention to adopt ICT; $R^{2}$ : Coefficient of determination

The results in Table 7 show that the five variables have a positive and significant influence on the behavioural intentions of secondary school teachers to adopt and use ICT, demonstrating that $\mathrm{H} 1, \mathrm{H} 2, \mathrm{H} 3, \mathrm{H} 3, \mathrm{H} 4$ and $\mathrm{H} 5$ were all valid. The use of ICT (UIT) for teaching has the highest standardized coefficient value $(\beta=.483 ; \mathrm{t}=$ 5.701; $\mathrm{p}=003 ; \mathrm{p}<.05)$, showing that it has the highest influence towards ICT adoption and use by secondary school teachers. Professional development in ICT 
(PD) has the second highest standardized coefficient $(\beta=.365 ; \mathrm{t}=3.664 ; \mathrm{p}=.007$; $\mathrm{p}<.05)$, showing that it is the second most influential factor on the adoption and use of ICT by secondary school teachers. Institutional support services (ISS) have the third highest standardized coefficient $(\beta=.329 ; \mathrm{t}=7.382 ; \mathrm{p}=.000 ; \mathrm{p}<.05)$, indicating that it is the third most influential factor on the adoption and use of ICT by secondary school teachers. Attitudes toward ICT has the fourth highest influence on the behavioural intentions of secondary school teachers to adopt and use ICT $(\beta=.301 ; \mathrm{t}=13.266 ; \mathrm{p}=.000 ; \mathrm{p}<.05)$. Results further show that of the five factors, gender (GE) has the lowest standardized coefficient $(\beta=.103 ; \mathrm{t}=4.825 ; \mathrm{p}$ $=.010 ; \mathrm{p}<.05)$, which was an indication that gender of secondary school teachers had the least influence on the behavioural intentions of secondary school teachers to adopt and use ICT.

With regard to the contribution of each of the variables to the variation in the adoption of ICT by secondary school teachers, the results in Table 7 show that gender contributes the highest variation of $62 \%$ to the behavioural intentions of secondary school teachers to adopt ICT, followed by professional development (58\%), institutional support services (51\%), attitudes toward ICT (49\%), and finally, the use of ICT for teaching, which contributes the least variation of $47 \%$ to the behavioural intention of secondary school teachers to adopt ICT. The whole model contributes $68 \%$ of the variation to the behavioural intentions of secondary school teachers to adopt and use ICT in their classrooms.

\section{Discussion}

The purpose of the study was to establish determinants of behavioural intentions of secondary school teachers in Zimbabwe to adopt and use technology. The TAM was used as a theoretical framework that informed the study. Factors that include the use of ICT for teaching (UIT), professional development in ICT (PDI), ICT support services, attitudes toward ICT and gender (GE) were tested to determine whether they influenced teachers' behavioural intentions to adopt and use ICT in secondary schools.

It was established in the study that teaching using ICT has a significant and positive influence on the behavioural intentions of secondary school teachers to adopt and use ICT. These results suggest that teachers who frequently teach using technology in their classes tend to find the technology useful and eventually are highly likely to develop behavioural intentions to adopt and use it. These results are consistent with findings of earlier studies. In their study also, Tri Anni et al. (2018) established that teachers who use ICT for teaching perceive ICT as useful to the performance of their tasks and tend to develop behavioural intentions to adopt and use it. Kong (2019), Orser et al. (2019) and Wong et al. (2012) also established that teachers who use ICT in teaching believing that the use of such ICT in their teaching will make the performance of their tasks easier and more productive, tend to eventually develop behavioural intentions to adopt the technology in their classrooms.

It also emerged in the current study that professional development of teachers in ICT has a significant and positive influence on their behavioural intentions to 
adopt and use it. This suggests that teachers who receive professional development training in ICT develop behavioural intentions to adopt and use the ICT because of the knowledge and skills they would have acquired. A study by Tri Anni et al (2018) found that teachers who undergo periodic training in ICT develop confidence in the use of ICT and are more likely to develop behavioural intentions to adopt it when compared to those who do not undergo periodic training. Separate studies by Marios (2020) and De Clercq and Shalem (2014) also found that teacher professional development in ICT helps teachers acquire particular ICT knowledge, skills and attitudes that help in the development confidence in the teachers as well as behavioural intentions to adopt the ICT for teaching.

Results of this study indicated that ICT support services have a significant and positive effect on the behavioural intentions of secondary school teachers to adopt ICT. These results suggest that for teachers to develop behavioural intentions to adopt ICT, schools must have an ICT support infrastructure that include a team of qualified ICT support staff that are capable of offering timely and effective support to the teachers. The results also suggest that schools should also have supportive institutional management, which ensures that all necessary ICT resources are available as needed by students and their teachers. Such support will give the teachers the much-needed confidence and motivation to use ICT leading to the development of positive attitudes toward as well as behavioural intentions to adopt ICT. These results confirm findings of earlier studies. Separate studies by Baturay et al. (2017) and Teeroovengadum et al. (2017) established that a supportive institutional environment that has adequate ICT systems maintenance and update tools, adequately trained ICT support personnel, and a supportive leadership, is a vehicle for promoting behavioural intentions by teachers to adopt ICT.

It also emerged from the study that attitudes of teachers towards ICT have a significant influence on their behavioural intentions to adopt ICT. These results suggest that the nature of attitudes, whether positive or negative, have a significant effect on whether or not teachers adopt ICT. This means that teachers with positive attitudes towards ICT are more likely to adopt ICT while those with negative attitudes are also less likely to adopt ICT. This is in line with findings of earlier studies. De-Graft (2018) in his study found that teachers who have positive attitudes towards ICT, more often than not, develop behavioural intentions to adopt that technology.

It further emerged from the study that gender has a significant and positive influence on the behavioural intentions of secondary school teachers to adopt ICT. The issue of gender differences in the adoption of technology has been widely studied with conclusions showing mixed results with regard to whether gender significantly affects behavioural intentions of teachers to adopt technology. In the context of the current study, the results suggest that there are gender differences in the behavioural intentions of teachers to adopt technology. These results are consistent with findings of earlier studies. As Dosaya, et al. (2020) found in their study, female teachers are more likely to use technology for teaching only when 
they perceive the technology to be easy to use. A study by Pham et al., (2020) also found that there are significant differences between male and female teachers with regard to behavioural intentions to adopt and use technology due to the fact that male teachers hold the belief that using technology helps them perform their tasks better while female teachers mostly use technology when they believe the effort required to use technology is minimum.

The findings of the study were that the behavioural intentions to adopt technology by teachers are affected by a number of challenges. Such challenges include inadequate ICT infrastructure, high costs of data bundles, high costs of ICT support technologies and maintenance, as well as unreliable power supplies among others. These challenges have slowed the speed by which ICT is integrated into the education system. A number of studies alluded to these challenges. Separate studies by UNESCO (2017), Machivenyika (2018), Mandina (2015) and Manhibi (2019) found that the above challenges were among some of the main challenges that are affecting the adoption of ICTs in schools.

\section{Limitations of the study}

The study used a quantitative approach only to establish factors influencing the behavioural intentions of secondary school teachers to adopt and use ICT and this may have potentially limited the breadth and depth of the study. Future studies can also use a qualitative or mixed methods approach on the same topic.

\section{Conclusion}

The purpose of the study was to establish factors that act as predictors of behavioural intentions of secondary school teachers to adopt and use ICT in their classrooms. The study was informed by the Technology Acceptance Model (TAM) from which a research model was designed. Based on the findings of this study, it was concluded that teachers who view technology as being easy to use, useful to their tasks, who receive adequate technical support from ICT support teams, and undergo professional development training in the use of ICT, are highly likely to develop behavioural intentions to adopt ICT. This means that the following factors: the use of ICT for teaching, professional development of staff, institutional support services, attitudes toward ICT significantly influenced the likelihood of secondary school teachers to adopt and use ICT in their classrooms. It was also concluded that gender has a significant influence on the likelihood of secondary school teachers adopting ICT in their classrooms with male teachers showing greater propensity to adopt and use technology compared to female teachers.

\section{Recommendations and Practical Implications}

A number of recommendations were made based on the results of the study. It was recommended that since technology has become a requirement for teaching and learning in schools in this digital era and also due to pandemics such as COVID-19, it is important that teachers develop positive attitudes towards and behavioural intentions to adopt and use technology. It was also recommended that secondary schools needed to recruit qualified ICT support staff who are able to offer timely and effective technical support to teachers. Due to high internet costs, it was also recommended that schools needed to enter into partnerships 
with industry for some forms of collaborations, which could lead to sponsorships. Continuous and periodic training of teachers in ICT was also recommended as a critical process for re-skilling and up-skilling teachers with necessary ICT knowledge and skills for them to continue having positive attitudes towards ICT and develop behavioural intentions to adopt and use ICT.

The adoption and use of ICT in teaching in secondary schools is critical not only for ensuring innovative teaching, but most importantly for enhancing access to education by students. This study therefore provides practical implications for the effective adoption and use of technology in schools. Firstly, the study demonstrates that professional development is important for confidence building and motivation of teachers to be able to develop behavioural intentions to adopt and use ICT. Secondly, the study highlights the importance of ICT support infrastructure, supportive institutional leadership, as well as the development of positive attitudes in teachers as strategies for ensuring the development of behavioural intentions to adopt and use ICT by teachers. Finally, the study has implications on both policy and practice on enhancing the adoption of ICT by teachers in secondary schools.

\section{Acknowledgements}

The researchers wish to thank all teachers and their institutional management for the successful completion of this study.

\section{References}

Abuhmaid, A. (2011). ICT training courses for teacher professional development in Jordan. Turkish Online Journal of Educational Technology-TOJET, 10(4), 195-210.

Ardies, J., De Maeyer, S., Gijbels, D., \& van Keulen, H. (2015). Learners' attitudes towards technology. International Journal of Technology and Design Education, 25(1), 43-65.

Attis, J. (2014). An investigation of the variables that predict teacher e-learning acceptance. [Doctoral thesis, Libert University, Lynchburg, VA].

Aung T. N., \& Khaing S. S. (2016) Challenges of implementing e-Learning in developing countries: A Review. In T. Zin, J.W. Lin, J. S. Pan, P. Tin, M. Yokota (Eds.) Genetic and Evolutionary Computing. GEC 2015. Advances in Intelligent Systems and Computing, vol 388. Springer, Cham.

Baishakhi, B., \& Kamal, D. (2016). Role of ICT in 21st century's teacher education. International Journal of Education and Information Studies, 6(1), 1-6.

Baturay, M. H., Gökçearslan, Ş., \& Ke, F. (2017). The relationship among pre-service teachers' computer competence, attitude towards computer-assisted education, and intention of technology acceptance. International Journal of Technology Enhanced Learning, 9(1), 1-13.

Binglimas, K. (2009). Barriers to the successful integration of ICT in teaching and learning environments: A review of the literature. Eurasia Journal of Mathematics, Science $\mathcal{E}$ Technology Education, 5(3), 235-245.

Broos, A. (2005). Gender and information and communication technologies (IT) anxiety: Male self-assurance and female hesitation. Cyber Psychology \& Behaviour, 8(1), 2131.

Buckenmeyer, J. A. (2010). Beyond computers in the classroom: Factors related to technology adoption to enhance teaching and learning. Contemporary Issues in Education Research, 3(4), 27. 
Christopouloshttps, A. \& Sprangers, P. (2021). Integration of educational technology during the Covid-19 pandemic: An analysis of teacher and student receptions. Cogent Education, 8(1), 1-27. https:/ / doi.org/10.1080/2331186X.2021.1964690

Christopoulos, A., Conrad, M., \& Shukla, M. (2018). Increasing student engagement through virtual interactions: How? Virtual Reality, 22(4), 353-369. https://doi.org/10.1007/s10055-017-0330-3.

Creswell, J. W., \& Plano Clark, V. L. (2017). Designing and conducting mixed methods research, 3rd ed. Thousand Oaks, CA: Sage.

Davis, F. D. (1989). Perceived Usefulness, Perceived Ease Of Use, And User Acceptance. MIS Quarterly, 13(3), 319-340.

De Clercq, F., \& Shalem, Y. (2014). Teacher knowledge and employer-driven professional development: A critical analysis of the Gauteng Department of Education programmes. Southern African Review of Education with Education with Production, 20(1), 129-147.

Dlamini, R., \& Mbatha, K. (2018). The discourse on ICT teacher professional development needs: The case of a South African teachers' union. International Journal of Education and Development using Information and Communication Technology (IJEDICT), 14 (2), 17-37.

Dosaya, D., Shukla, T., \& Nirban, V.S. (2020). Transformation of Academic Ecology through Information Communication Technology adoption. International Journal of Information and Education Technology, 10(5), 372-377.

Dzinotyiweyi, M., \& Taddese, A. (2020). EdTech in Zimbabwe: A rapid scan (EdTech Hub 2, country scan No. 4). https:/ / doi.org/10.5281/zenodo.3903838

De-Graft, J. D. (2018). Assessing the use of Information and Communication Technology in teaching and learning in secondary schools. Library Philosophy and Practice. https://www.researchgate.net/publication/328931869_The_Adoption_and_use _of_Ict_in_Teaching_and_Learning_in_Secondary_Schools

Francom, G. M. (2020). Barriers to technology integration: A time-series survey study. Journal of Research in Technology Education, 52(1), 1-16. https:// doi.org/10.1080/15391523.2019.1679055

Gebre, E., Saroyan, A., \& Bracewell, R. (2014). Learners' engagement in technology rich classrooms and its relationship to professors' conceptions of effective teaching. British Journal of Educational Technology, 45(1), 83-96.

Ghavifekr, S., \& Rosdy, W. A. W. (2015). Teaching and learning with technology: Effectiveness of ICT integration in schools. International Journal of Research in Education and Science (IJRES), 1(2), 175-191.

Hair, J. F., Hult, G. T. M., Ringle, C. M., \& Sarstedt, M. (2017). A primer on partial least squares structural equation modelling (PLS-SEM) (2nd ed.). Thousand Oaks, CA: Sage.

Hair, J. F., Hult, G. T. M., Ringle, C. M., \& Sarstedt, M. (2014). A primer on partial least squares structural equation modelling (PLS-SEM). Thousand Oaks, CA: Sage.

Hamadin, K. (2017). Implementation e-learning among Jordanian School's Management. Journal of Education and Practice, 8(11), 79-87.

Hayes, D. N. A. (2007). ICT and learning: Lessons from Australian classrooms. Computers \& Education, 49(2), 385-395.

Kay, R. (2006). Addressing gender differences in computer ability, attitudes and use: The laptop effect. Journal of Educational Computing Research, 34(2), 187-211.

Kong, S. C. (2019). Partnership among schools in e-Learning implementation: Implications on elements for sustainable development. Educational Technology \& Society, 22(1), 28-43. 
Konyana, S., \& Konyana, E. G. (2013). Computerization of rural schools in Zimbabwe: Challenges and opportunities for sustainable development: the case of Chipinge District, South-East Zimbabwe. African Journal of Teacher Education, 2(3), 1-13.

Machivenyika, F. (2018, March 15). President launches national ICT policy. The Herald. https://www.herald.co.zw/just-in-president-launches-ict-policyframework/

Mandina, S. (2015). Integrating ICTs into the environmental science primary school classroom in Chegutu district, Zimbabwe: problems and solutions. European Journal of Science and Mathematics Education, 3(1), 90-96.

Manhibi, R, (2019). Information and Communication Technologies integration into early childhood development education in Masvingo Province, Zimbabwe: A Critical Analysis. $\mathrm{PhD}$ Dissertation submitted to the University of Kwazulu-Natal, SA.

Mansour, N., Alshamrani, S., Aldahmash, A., \& Alqudah, B. (2011). Perceived professional development needs for Saudi Arabian science teachers. https://www.esera.orh/media/

Mario, C. (2020, February 20). Complementary Hypotheses for Technology Analyses and Innovation Management. Working Paper CocciaLab n. 46/2020, CNR -- National Research Council of Italy, 2020. https:// ssrn.com/abstract=3541596.

Mayer, R. E. (2019). Computer games in education. Annual Review of Psychology, 70(1), 531549. https:// doi.org/ 10.1146/annurev-psych-010418-102744.

McCombes, S. (2020). Descriptive research. https://www.scribbr.com/methodology/descriptive-research/

Mishra, M. P., Sharma, V. K., \& Tripathi, R. C. (2008). ICT as a tool for teaching and Learning in Respect of learner with disability. http://wikieducator.org/images/7/7b/SJ\%7B_\%7DM.P.Mishra.pdf

Musarurwa, T. (2018). Constant review vital for National ICT Policy. The Sunday Mail (Zimbabwe). https://www.sundaymail.co.zw/constant-review-vital-fornational-ict-policy

Mutisya, D. N., \& Makokha, G. L. (2016). Challenges affecting adoption of e-learning in public universities in Kenya. E-Learning and Digital Media, 13(3-4), 140-157.

Mutuku, M. N. (2018). An investigation of the factors influencing the integration of ICT in teaching and learning process in public secondary schools in Machakos county, Kenya. International Journal of Economics, Commerce and Management, VI(4), 418441.

Nikolopoulou, K., \& Gialamas, V. (2015). Barriers to the integration of computers in early childhood settings: Teachers' perceptions. EAIT, 20(2), 285-301. https:// doi.org/10.1007/s10639-013-9281-9

Odhiambo, O. S. (2013). Use of information communication technology in teaching and learning processes in secondary schools in Rachuonyo South District, Homa-bay County, Kenya. Masters Dissertation, University of Nairobi.

OECD. (2019). TALIS 2018 Results (Volume I): Teachers and school leaders as lifelong Learners. TALIS, OECD Publishing, Paris, https://doi.org/10.1787/1d0bc92a-en

Orji, R. (2010) Impact of gender and nationality on acceptance of a digital library: An empirical validation of nationality based UTAUT using SEM. Journal of Emerging Trends in Computing and Information Sciences, 1, 68-79.

Orser, B., Riding, A., \& Li, Y. (2019). Technology adoption and gender-inclusive entrepreneurship education and training. International Journal of Gender and Entrepreneurship, 11(3), 273-298.

Oscarson, D. J. (1976). Factors associated with vocational teacher proneness toward the adoption of innovations. Unpublished doctoral dissertation, Virginia Polytechnic Institute and State University. 
Perrotta, C. (2013). Do school-level factors influence the educational benefits of digital technology? A critical analysis of teachers' perceptions. British Journal of Educational Technology, 44(2), 314-327.

Pham, T. B. T., Danga, L. A., Lea, T. M. H., \& Lea, T. H. (2020). Factors affecting teachers' behavioral intention of using information technology in lecturing economic universities. Management Science Letters, 10, 2665-2672.

Reich, J. (2020). Failure to Disrupt: Why technology alone can't transform education. Harvard University Press.

Reyna, J. (2016). Bringing Knowledge to Life: Implementing e-learning across the School of Education. International Journal on E-Learning, 15(1), 101-120.

Rudhumbu, N. (2020). Antecedents of university lecturers' intentions to adopt information and communication technology in Zimbabwe. Education and Information Technologies, 6, 127-143.

Scherer, R., Siddiq, F., \& Tondeur, J. (2019). The technology acceptance model (TAM): A meta-analytic structural equation modeling approach to explaining teachers' adoption of digital technology in education. Computers \& Education, 128, 13-35. https://doi.org/ 10.1016/j.compedu.2018.09.009

Schoonenboom, J. (2014). Using an adapted, task-level technology acceptance model to explain why instructors in higher education intend to use some learning management system tools more than others. Computers \& Education, 71, 247-256.

Teeroovengadum, V., Heeraman, N., \& Jugurnath, B. (2017). Examining the antecedents of ICT adoption in education using an extended technology acceptance model (TAM). International Journal of Education and Development using Information and Communication Technology (IJEDICT), 13(3), 4-23.

Teo, T., Fan, X., \& Du, J. (2015). Technology acceptance among pre-service teachers: Does gender matter? Australasian Journal of Educational Technology, 31(3), 235-251.

Teo, T., \& Huang, F. (2018). Investigating the influence of individually espoused cultural values on teachers' intentions to use educational technologies in Chinese universities. Interactive Learning Environments. https://doi.org/10.1080/10494820.2018.1489856

Teo, T., Huang, F., \& Hoi, C. K. W. (2018). Explicating the influences that explain intention to use technology among English teachers in China. Interactive Learning Environments, 26(4), 460-475.

Teo, T., Lee, C. B., \& Chai, C. S. (2008). Understanding pre-service teachers' computer attitudes: Applying and extending the Technology Acceptance Model. Journal of Computer Assisted Learning, 24(2), 128-143.

Teo, T. (2019). Learners and teachers' intention to use technology: Assessing their measurement equivalence and structural invariance. Journal of Educational Computing Research, 57(1), 201-225.

Thatcher, J. B., \& Perrewé, P. L. (2012). An empirical examination of individual traits as antecedents to computer anxiety and computer self-efficacy. MIS Quarterly, 26(4), 381-396.

The Research Advisors. (2006). Sample size table. https://www.researchadvisors.com/tools/SampleSize.htm

Tondeur, J., Aesaert, K., Pynoo, B., Braak, J., Fraeyman, N., \& Erstad, O. (2017). Developing a validated instrument to measure preservice teachers' ICT competencies: Meeting the demands of the 21st century. British Journal of Educational Technology, $48(2), 462-472$.

Tri Anni, C., Sunawan, S., \& Haryono, H. (2018). School counselors' intention to use technology: The technology acceptance model. 
https://www.researchgate.net/publication/324438702_School_Counselors'_Int ention_to_Use_Technology_The_Technology_Acceptance_Model.

UNESCO. (2017). Report of the Southern Africa Regional Meeting on ICTs in Education. http://www.unesco.org/new/fileadmin/multimedia/field/Harare/pdf/ICTs EDZIM.pdf

UNESCO. (2020). The Global Risk Report. New York: Henslin Press.

Venkatesh, V., \& Bala, H. (2008). Technology Acceptance Model 3 and a research agenda on interventions. Decision Science, 39(2), 273-312.

Vongkulluksn, V. W., Xie, K., \& Bowman, M. A. (2018). The role of value on teachers' internalization of external barriers and externalization of personal beliefs for classroom technology integration. Computers $\mathcal{E}$ Education, 118(3), 70-81.

Wang, H. Y., \& Wang, S. H. (2010). User acceptance of mobile Internet based on the unified theory of acceptance and use of technology: Investigating the determinants and gender differences. Social Behavior and Personality, 38(3), 415.

Welch, T. (2012). Teacher Development: What works and how can we learn from this and maximise the benefits? Presentation at the Teachers' Upfront meeting. Johannesburg: Wits School of Education.

Williams, D., Coles, L., Richardson, A., Wilson, K., \& Tuson, J. (2000). Integrating Information and Communications Technology in Professional Practice: An analysis of teachers' needs based on a survey of primary and secondary teachers in Scottish schools. Journal of Information Technology for Teacher Education, 9, 167182.

Wong, K., Teo, T., \& Russo, S. (2012). Influence of gender and computer teaching efficacy on computer acceptance among Malaysian student teachers: An extended technology acceptance model. Australasian Journal of Educational Technology, 28(7), 1190-1207.

Zhu, C., \& Urhahne, D. (2018). The use of learner response systems in the classroom enhances teachers' judgment accuracy. Learning and Instruction, 58, 255-262. https://doi.org/10.1016/j.learninstruc.2018. 07.011

Zimbabwe Ministry of Primary and Secondary Education. (2019). ICT Policy for Primary and Secondary Education (2019 https://docs.edtechhub.org/lib/ZK7M3DZ9

Zimbabwe National Statistics Agency. (2017). Information and Communications Technology (ICT) Census. https://docs.edtechhub.org/lib/TWM5YZVL 


\section{Appendix}

\section{QUESTIONNAIRE FOR TEACHERS}

RESEARCH TITLE: Predictors of behavioural intentions of teachers to adopt and use information and communication technologies in secondary schools

\section{INSTRUCTIONS:}

You are requested to take about 20 minutes to answer the following questionnaire. Kindly use $\mathrm{X}$ in the box bearing your choice of response to each of the given statements.

\section{SECTION A: DEMOGRAPHIC PROFILES}

1. Age: $21-30$ yrs.

31-40 yrs

41-50 yrs.

$50+\mathrm{yrs} \square$

2. Gender: Male

Female

3. Educational level: C.E

Dip.Ed.

Bachelor's degree

Master's degree

Other

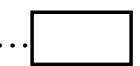

4. Teaching experience: $<5$ yrs.

$5-10$ yrs.

$11-20$ yrs.

$20+$ yrs

5. Level taught: Form 1

Form 2

Form 3

Form 4

6. Area of specialization: Sciences

Arts and social sciences

Commerce

Creative arts

ICT

SECTION B: FACTORS INFLUENCING ICT ADOPTION

\begin{tabular}{|l|l|l|l|l|l|l|}
\hline \multicolumn{2}{|l|}{ Use of ICT for teaching } & SDA & DA & N & A & SA \\
\hline SN & ITEM & 1 & 2 & 3 & 4 & 5 \\
\hline 1. & $\begin{array}{l}\text { I use technology for teaching most of the } \\
\text { time. }\end{array}$ & & & & & \\
\hline 2. & I am confident of teaching using technology. & & & & & \\
\hline 3. & $\begin{array}{l}\text { Teaching using technology helps in } \\
\text { facilitating collaborative teaching. }\end{array}$ & & & & & \\
\hline 4. & I enjoy teaching using technology. & & & \\
\hline 5. & $\begin{array}{l}\text { The academic performance of my students } \\
\text { improves when I teach using technology. }\end{array}$ & & & & & \\
\hline 6. & $\begin{array}{l}\text { My ability to teach improves when I teach } \\
\text { using technology. }\end{array}$ & & & & & \\
\hline 7. & $\begin{array}{l}\text { My communication with both students and } \\
\text { their parents improves when I teach using } \\
\text { technology. }\end{array}$ & & & & & \\
\hline 8. & $\begin{array}{l}\text { My lesson planning has improved as a } \\
\text { result of teaching using technology. }\end{array}$ & & & & & \\
\hline 9. & $\begin{array}{l}\text { Teaching using technology makes my lesson } \\
\text { interactive and interesting. }\end{array}$ & & & & & \\
\hline 10. & $\begin{array}{l}\text { Teaching using technology has improved } \\
\text { the motivation levels of my students. }\end{array}$ & & & & & \\
\hline
\end{tabular}




\begin{tabular}{|c|c|c|c|c|c|c|}
\hline \multicolumn{7}{|c|}{ Professional development in ICT } \\
\hline SN & ITEM & SDA & DA & $\mathrm{N}$ & $\mathrm{A}$ & SA \\
\hline & & 1 & 2 & 3 & 4 & 5 \\
\hline 11. & $\begin{array}{l}\text { Professional development in ICT helps } \\
\text { develop confidence in me to use technology } \\
\text { for teaching. }\end{array}$ & & & & & \\
\hline 12. & $\begin{array}{l}\text { I find professional development in ICT very } \\
\text { meaningful at my institutions. }\end{array}$ & & & & & \\
\hline 13. & $\begin{array}{l}\text { Professional development in ICT is } \\
\text { frequently done at my institution. }\end{array}$ & & & & & \\
\hline 14. & $\begin{array}{l}\text { Professional development in ICT has helped } \\
\text { teaching staff at my institution gain } \\
\text { confidence in using technology for teaching. }\end{array}$ & & & & & \\
\hline 15. & $\begin{array}{l}\text { Teachers at my institution now frequently } \\
\text { use technology for teaching because of the } \\
\text { professional development trainings in ICT } \\
\text { they frequently receive. }\end{array}$ & & & & & \\
\hline 16. & $\begin{array}{l}\text { Professional development in ICT has helped } \\
\text { me to be able to use a multimedia approach } \\
\text { to teaching. }\end{array}$ & & & & & \\
\hline \multicolumn{7}{|c|}{ ICT support services } \\
\hline SN & & SDA & DA & $\mathrm{N}$ & $\mathrm{A}$ & SA \\
\hline 17. & $\begin{array}{l}\text { I have happy with the support given to ICT } \\
\text { by institutional management. }\end{array}$ & 1 & 2 & 3 & 4 & 5 \\
\hline 18. & $\begin{array}{l}\text { We have state of the art ICT infrastructure to } \\
\text { support our teaching at y institution. }\end{array}$ & & & & & \\
\hline 19. & $\begin{array}{l}\text { We have well trained technical staff to assist } \\
\text { us in the use of technology at our } \\
\text { institution. }\end{array}$ & & & & & \\
\hline 20. & $\begin{array}{l}\text { I am happy with the state of ICT systems } \\
\text { support and maintenance at our institution. }\end{array}$ & & & & & \\
\hline 21. & $\begin{array}{l}\text { There is adequate budget to support ICT } \\
\text { needs at our institution. }\end{array}$ & & & & & \\
\hline \multicolumn{7}{|c|}{ Attitudes toward ICT } \\
\hline & & SDA & $\begin{array}{l}\mathrm{D} \\
\mathrm{A}\end{array}$ & $\mathrm{N}$ & $\mathrm{A}$ & SA \\
\hline & & 1 & 2 & 3 & 4 & 5 \\
\hline \multicolumn{7}{|c|}{$\begin{array}{l}\text { 22. I feel apprehensive about using technology for } \\
\text { teaching. }\end{array}$} \\
\hline \multicolumn{7}{|c|}{$\begin{array}{l}\text { 23. I sometimes get nervous just thinking about } \\
\text { technology. }\end{array}$} \\
\hline \multicolumn{7}{|c|}{ 24. Teaching using technology is boring to me. } \\
\hline \multicolumn{7}{|c|}{$\begin{array}{l}\text { 25. I feel that technology isolate teachers by } \\
\text { inhibiting normal social interactions among } \\
\text { users. }\end{array}$} \\
\hline \multicolumn{7}{|c|}{$\begin{array}{l}\text { 26. I do not like using technology for teaching } \\
\text { because I feel it has the potential to control } \\
\text { our lives in terms of how we think and act. }\end{array}$} \\
\hline 27. & $\begin{array}{l}\text { do not have time to waste learning a lot } \\
\text { bout technology. }\end{array}$ & & & & & \\
\hline
\end{tabular}




\begin{tabular}{|c|c|c|c|c|c|}
\hline $\begin{array}{l}\text { 28. Knowing how to use technology is a } \\
\text { worthwhile skill. }\end{array}$ & & & & & \\
\hline 29. I like working with technology every time. & & & & & \\
\hline Gender & & & & & \\
\hline & SDA & $\begin{array}{l}\mathrm{D} \\
\mathrm{A}\end{array}$ & $\mathrm{N}$ & $\mathrm{A}$ & SA \\
\hline & 1 & 2 & 3 & 4 & 5 \\
\hline $\begin{array}{l}\text { 30. There is a significant difference in the way } \\
\text { male and female teachers use technology for } \\
\text { teaching. }\end{array}$ & & & & & \\
\hline $\begin{array}{l}\text { 31. Female teachers are not very confident to use } \\
\text { technology in general. }\end{array}$ & & & & & \\
\hline $\begin{array}{l}\text { 32. Male teachers use technology because they } \\
\text { find it more useful for their performance. }\end{array}$ & & & & & \\
\hline $\begin{array}{l}\text { 33. Female teachers use technology only when } \\
\text { they feel it is easy to use. }\end{array}$ & & & & & \\
\hline Behavioural intentions (BI) & & & & & \\
\hline & SDA & $\begin{array}{l}\mathrm{D} \\
\mathrm{A}\end{array}$ & $\mathrm{N}$ & A & SA \\
\hline & 1 & 2 & 3 & 4 & 5 \\
\hline 34. I like using technology for teaching. & & & & & \\
\hline $\begin{array}{l}\text { 35. I would recommend other teachers to use } \\
\text { technology for teaching. }\end{array}$ & & & & & \\
\hline $\begin{array}{l}\text { 36. I find teaching using technology flexible that } \\
\text { will continue with it for as long as I am able. }\end{array}$ & & & & & \\
\hline $\begin{array}{l}\text { 37. Teaching using technology helps in building } \\
\text { my teaching confidence. }\end{array}$ & & & & & \\
\hline Barriers to ICT adoption & & & & & \\
\hline & SDA & $\begin{array}{l}\mathrm{D} \\
\mathrm{A}\end{array}$ & $\mathrm{N}$ & $\mathrm{A}$ & SA \\
\hline $\begin{array}{l}\text { The following affect my adoption of technology } \\
\text { for teaching: }\end{array}$ & 1 & 2 & 3 & 4 & 5 \\
\hline 38. Lack of ICT training & & & & & \\
\hline 39. Inadequate ICT resources & & & & & \\
\hline 40. Inadequate ICT support & & & & & \\
\hline 41. High internet costs & & & & & \\
\hline 42. Slow internet connectivity & & & & & \\
\hline 43. High costs of ICT gadgets & & & & & \\
\hline 44. Techno-phobia & & & & & \\
\hline 45. High workloads & & & & & \\
\hline 46. Negative perceptions towards ICT & & & & & \\
\hline 46. Lack of confidence & & & & & \\
\hline
\end{tabular}

THANK YOU FOR TAKING YOUR TIME TO RESPOND TO THE QUESTIONNAIRE 